\title{
Experimentation on Tool Wear and Surface Roughness in AISI D2 Steel Turning with WC Insert
}

\author{
N. López-Luiz'1*, 0. Jiménez Alemán², F. Alvarado Hernández³, M. Montoya Dávila3, \\ V. H. Baltazar-Hernández ${ }^{3}$ \\ ${ }^{1}$ Centro de Tecnología Avanzada, CIATEQ, Doctorado en Manufactura Avanzada, Aguascalientes, México \\ ${ }^{2}$ Departamento de Ingeniería de Proyectos, CUCEI, Universidad de Guadalajara, Zapopan, Jal, México \\ ${ }^{3}$ Maestria en Ciencia e Ingeniería de los Materiales, Universidad Autónoma de Zacatecas, Zacatecas, México \\ Email: *norberto_lopez@ucol.mx
}

How to cite this paper: López-Luiz, N., Alemán, O.J., Hernández, F.A., Dávila, M.M. and Baltazar-Hernández, V.H. (2018) Experimentation on Tool Wear and Surface Roughness in AISI D2 Steel Turning with WC Insert. Modern Mechanical Engineering, 8, 204-220.

https://doi.org/10.4236/mme.2018.83014

Received: July 20, 2018

Accepted: August 26, 2018

Published: August 29, 2018

Copyright $\odot 2018$ by authors and Scientific Research Publishing Inc. This work is licensed under the Creative Commons Attribution International License (CC BY 4.0).

http://creativecommons.org/licenses/by/4.0/

(c) $\underset{\mathrm{EY}}{\mathrm{C}}$ Open Access

\begin{abstract}
The Taguchi method, based on an orthogonal arrangement $\left(\mathrm{L}_{9}, 3^{3}\right)$, the variance analysis, the signal-to-noise ratios and the response surface methodology have been used to optimize maximum flank wear $\left(\mathrm{VB}_{\max }\right)$ and surface roughness $(\mathrm{Ra})$ of the cutting tool when turning a hardened steel AISI D2 (65 HRC) with PVD-TiAlN coated WC insert upon dry environment. By employing regression models; cutting speed, cutting depth and feed rate, which optimize maximum flank wear and surface roughness were validated. Results of relation signal-to-noise ratios, showed that with cutting speed of 200 $\mathrm{m} / \mathrm{min}$, cutting depth of $0.2 \mathrm{~mm}$ and feed rate of $0.20 \mathrm{~mm} / \mathrm{rev}$, Ra is optimized. With cutting speed of $150 \mathrm{~m} / \mathrm{min}$, cutting depth of $0.4 \mathrm{~mm}$ and feed rate of $0.3 \mathrm{~mm} / \mathrm{rev}, \mathrm{VB}_{\max }$ is optimized. Through the variance analysis it was concluded that the depth of cut was the main parameter that affected on the surface roughness; whereas, the feed rate was the most influential parameter on the flank wear. Confirmation test results showed that the Taguchi method was very successful in the optimization of machining parameters for minimum surface roughness and flank wear in the turning of the D2 steel.
\end{abstract}

\section{Keywords}

Turning, Taguchi Method, Wear of Cutting Tool, Surface Roughness, AISI D2

\section{Introduction}

In recent years, wear resistant thin film hard coatings in single layer or multilay- 
er form developed which bring a great breakthrough in metal cutting industry. Cutting parameters may be specified according to hardness of materials and roughness of the surface of a work piece. The advantages in machining materials with higher hardness are decreasing machining costs, saving time, improving surface quality, and eliminating of deformities in parts caused by temperature [1]. The economic aspects and the enhanced ecologic responsibility, as well as results of the latest research indicating a hazardous influence of emulsions draws the industries attention to alternative machining technologies i.e. dry machining.

From the literature, studies related on exact tool wear mechanisms and surface finish during turning of high carbon high chromium D2 cold work tool steel with increasing level of hardness using multilayer coated WC inserts are limited. It is difficult to machines owing to their high carbon and high chromium content and thus machinability is poor. At the same time it is also important to know the results when using coated WC tools, mainly for economical reasons though it is otherwise machined by costly ceramic and CBN tools [2].

G. Zheng et al. [3] experimented in high-speed dry turning of $300 \mathrm{M}$ high strength steel with coated carbide tool is conducted. It is suggested that the cutting speed has the most important effect on the cutting force, cutting temperature and tool life, while the feed rate has great influence on surface roughness.

S. A. Khan [4] investigated the effect of wiper inserts' microgeometry for critical hardness regime of the material, employed two distinct edge geometries for wiper inserts in finish hard turning of AISI D2 steel without cutting fluid, machining workpieces of two different hardness (55HRC and 60HRC). Workpiece hardness was found to play the most significant role for tool life whereas for surface roughness, insert type and feed rate are found to be more dominant, maximum wear scar has been observed at the minor cutting edge with "Notching" being the prevalent wear mode. Microhardness was seen to be increased beneath the machined surface for both new and worn tools up to a depth of 200 $\mu \mathrm{m}$. At highest feed $(0.281 \mathrm{~mm} / \mathrm{rev})$ and depth of cut $(0.20 \mathrm{~mm})$ combination, material pull-out was revealed as the major microstructural damage.

Davim and Figueira [5], concerning the machinability evaluation of cold-work tool steel (D2) using statistical techniques, presented that with an appropriate choice of cutting parameters it is possible to obtain a surface roughness with Ra $<0.8 \mu \mathrm{m}$. This implies that hard machining is an alternative competitive process, which allows eliminating cylindrical grinding operation solutions. The tool wear is highly influenced by the cutting velocity $(57.4 \%)$ and, in a smaller degree, by cutting time (13.4\%). O. J. Onuoha et al. [6] employed the Taguchi method to investigate the effects of cutting fluids on surface roughness in turning AISI 1330 alloy steel, using manually operated lathe machine. The statistical methods of Signal-to-Noise ( $/ \mathrm{N}$ ) ratio and the Analysis of Variance (ANOVA) were applied to investigate effects of cutting speed, feed rate and depth of cut on surface roughness under different cutting fluids. Results obtained indicated that optimal variables for the minimum surface roughness were cutting speed of $35 \mathrm{~m} / \mathrm{min}$ (level 2), feed of $0.124 \mathrm{~mm} / \mathrm{rev}$ (level 1), depth of cut of $0.3 \mathrm{~mm}$ (level 1) and a 
cutting fluid with a viscosity of $2.898 \mathrm{~mm}^{2} / \mathrm{s}$ (level 3). Hence, the optimal parameters to obtain better surface roughness of the workpiece material were obtained when groundnut oil based cutting fluid was used. ANOVA shows that feed rate has the most significant effect on surface roughness.

Özel et al. [7] observed that surface roughness (Ra) values is as low as 0.18 $0.20 \mu \mathrm{m}$ with wiper ceramic inserts during hard turning of AISI D2 steel (60 HRC). Tool flank wear reaches around 15 min considering flank wear criteria of $0.3 \mathrm{~mm}$ at high cutting speeds due to elevated temperatures. The high carbon high chromium AISI D2 steel was turned using Tungsten carbide insert (CNMG12408). The results have been compared with dry machining and near dry machining. The experimental results indicate that near dry machining (NDM) shows promising results over dry machining in terms of work-tool interface temperature and surface roughness. In order to obtain a good cutting performance by NDM, it is considered that at higher speeds better surface finish properties are obtained. Therefore, it is suggested that near dry machining, provides environment friendliness, cleaner production and can also help to improve the desirable machinability characteristics up to certain extent [8].

A. K. Sahoo and B. Sahoo [9] mentioned about optimization of process parameters to surface roughness and tool wear in hard turning finish of D2 steel with ceramic tools using the neural network model of radial function, being suitable for selecting the functional process parameters. Currently, research and experimentation in machining processes continues, in order to maximize useful life of the cutting tool and maintain surface and dimensional quality of the pieces within established specifications in the manufacturing industry. The current literature reports many investigations using PCBN and ceramic tool on hardened steel, but the research work carried out by multilayer coated carbide inserts on hard turning are very limited.

Thus, there is a need to investigate the machinability of hardened steel using low cost coated carbide insert in details to explore its feasibility in application in hard turning under dry environment. The present experimental investigation deals with relevant aspects of machinability such as the maximum flank wear of the cutting tool (VBmax) and surface roughness $(\mathrm{Ra})$ in hard turning of an AISI D2 steel (65 HRC), using WC inserts with TiAlN coating by physical vapor deposition (PVD) upon dry environment under high speed machining parameters. The Taguchi's parameter design approach, response surface method and regression models were used to achieve the objective optimizing flank wear of cutting tool and surface roughness of the machined part, depending on optimization of cutting parameters (cutting speed, depth of cut and feed rate). A statistical analysis (ANOVA) was performed to identify the process parameters that are statistically significant.

\section{Experimental Methods}

\subsection{Experimental Procedure}

The work piece used for experimentation was an AISI D2 steel with dimensions 
of $165.1 \mathrm{~mm}$ in length and $50.8 \mathrm{~mm}$ in diameter. The hardness of the steel before heat treatment measured $30 \mathrm{HRC}$; the steel was tempered at $1025^{\circ} \mathrm{C}$ for $30 \mathrm{~min}$ and quenched oil, after tempering and quenching hardness was 65 HRC. A CNC lathe model TITANIUM ${ }^{\mathrm{TM}}$, with control FANUC ${ }^{\mathrm{TM}}$ and maximum spindle speed $1620 \mathrm{rpm}$, was utilized. The machining was performed upon dry environment in order to evaluate the behavior of machined surface roughness and flank wear on the cutting tool. The cutting experiments were conducted using coated WC inserts ISO WNMG 432-MSPH6225, 80 ${ }^{\circ}$ negative rake angle, whit break chip and nose radius of $0.8 \mathrm{~mm}$, PVD-TiAlN coated. The inserts were rigidly mounted on a tool holder designated by ISOMWLNL16-4D. Figure 1 shows the chemical composition of the coating obtained through X-ray energy dispersion spectrometry (EDS).

The arithmetic average surface roughness $(\mathrm{Ra})$ of the workpiece was measured by employing a Mitutoyo ${ }^{\mathrm{TM}}$ SJ301 surface roughness tester as shown in Figure 2(a), where the cutoff length and assessment length was fixed as $0.8 \mathrm{~mm}$ and 4 $\mathrm{mm}$ respectively. The instrument was calibrated using a standard calibration block prior to the measurements. The measurement was taken at three locations $\left(120^{\circ}\right)$ around the circumference of the workpieces and two point on the long of the machined surface (counterpoint and end chuck), Figure 2(b). The average values of $\mathrm{Ra}$ were reported for the response (Table 2).

In the present study, the tool wear area was considered as the criterion and would affect the results of cutting process. The measurement in width of flank wear land of the cutting tool was used to evaluate the tool wear. The maximum value of flank wear $\left(\mathrm{VB}_{\max }\right)$ was adopted as the machinability evaluation when machining AISI D2 steel. In comparable research work, the maximum flank wear was measured at the tool corner $\left(\mathrm{VB}_{\max }\right)$ and the value $0.3 \mathrm{~mm}$ was adopted as criteria [2]. Here, the flank wear was measured using scanning electron microscope (SEM) micrographs as shown in Figure 3.

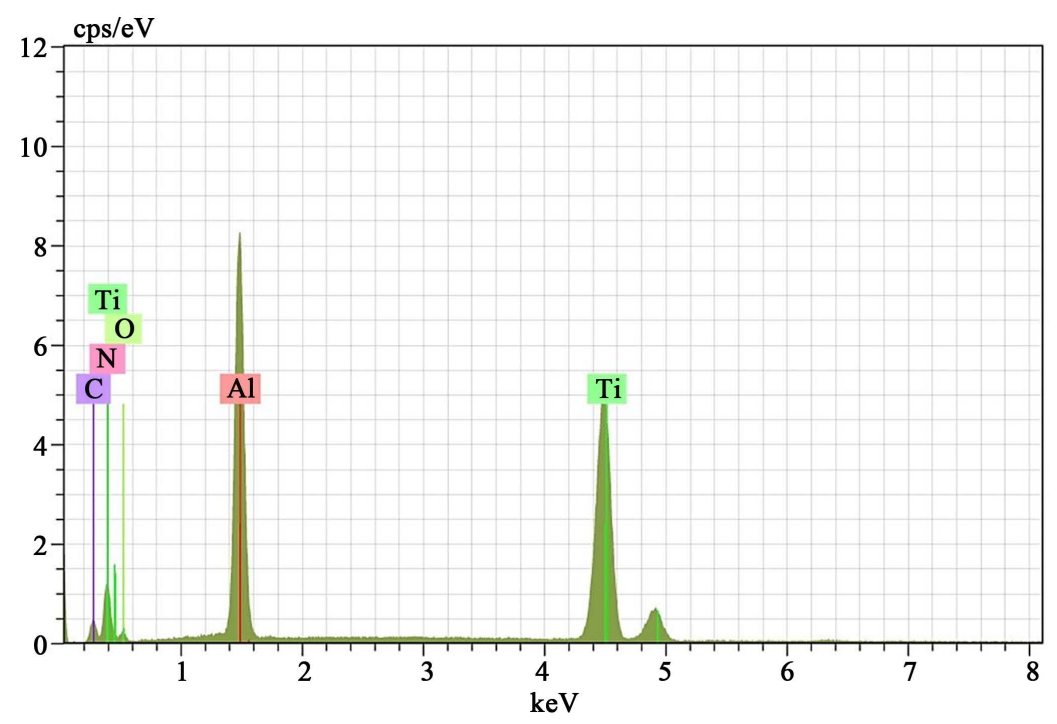

Figure 1. Chemical composition of coated, obtained by EDS in SEM. 


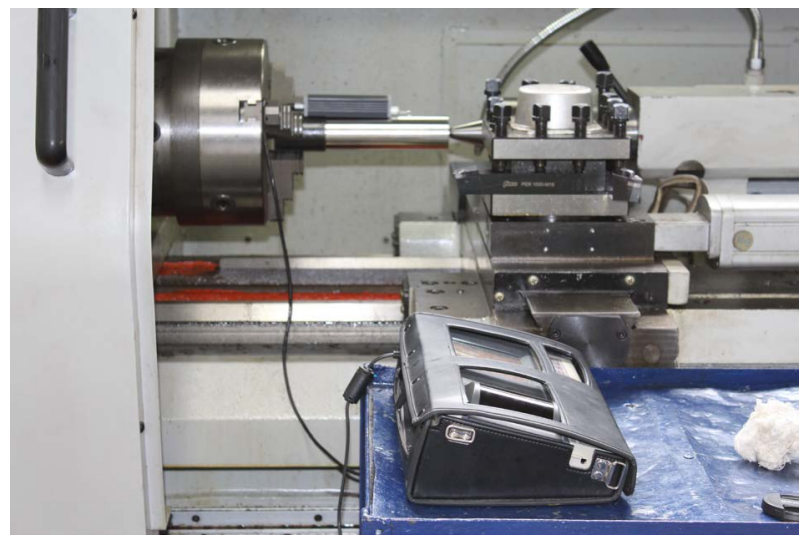

(a)

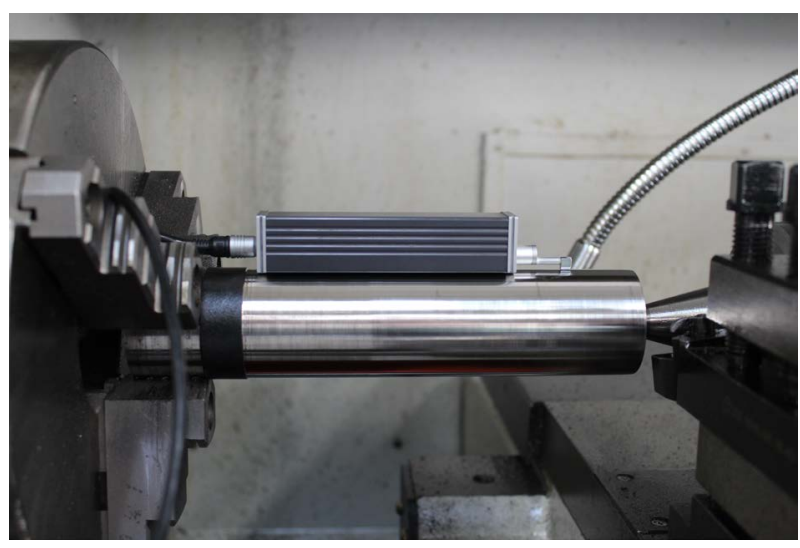

(b)

Figure 2. (a) Surface roughness tester; (b) Measurement of surface roughness in machined part.

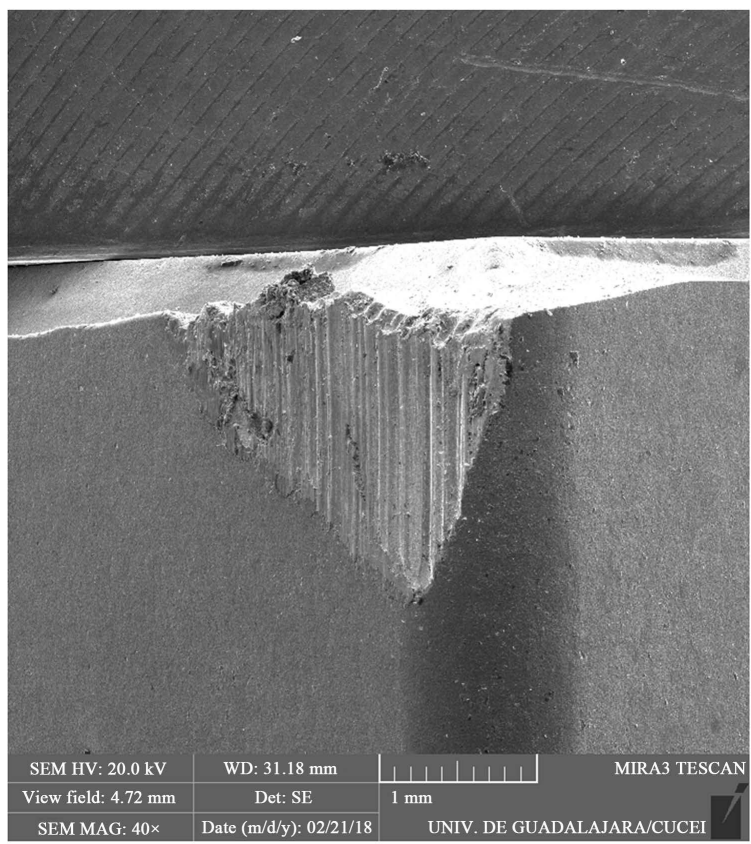

Figure 3. SEM micrograph of the flank wear cutting tools for: $\mathrm{Vc}=200 \mathrm{~m} / \mathrm{min}$, ap $=0.40$ $\mathrm{mm}$ and $\mathrm{f}=0.3 \mathrm{~mm} / \mathrm{rev}$. 


\subsection{Design of Experiment}

The Taguchi method is an experimental design technique, which is useful in reducing the number of experiments dramatically by using orthogonal arrays and also to minimize effects of the factors out of control. The most reliable of Taguchi method is the use of the parameter-design technique, which is an engineering method for product or process design that focuses on determining the parameter (factor) settings producing the best levels of a quality characteristic (performance measure) with minimum variation [1]. The Taguchi design experiments $\mathrm{L}_{9}, 3^{3}$ was used to establish the cutting parameters that optimize (minimize) the maximum wear of cutting tool flank $\left(\mathrm{VB}_{\max }\right)$ and the surface roughness (Ra). The cutting parameters and the conditions for machining AISI D2 steel are listed in Table 1. Three levels for each variable of cutting was established (low, medium, high), according of reported in [6], [8], [9] and dates recommended for tool manufacturing. Three variables of cutting up-on three levels led to a trial of 9 sets, Table 1.

The performance characteristic of the signal-to-noise ratio $(\mathrm{S} / \mathrm{N})$ used in this study is given by Equation (1), low the better, when the characteristic is continuous [10]:

$$
\mathrm{S} / \mathrm{N}=-10 \log \frac{1}{\mathrm{n}}\left(\sum \mathrm{y}^{2}\right)
$$

With the above $\mathrm{S} / \mathrm{N}$ ratio transformation; the highest the $\mathrm{S} / \mathrm{N}$ ratio, the better the result, when considering output tool wear and surface roughness. Table 2 shows the level values $\mathrm{S} / \mathrm{N}$ according to the Taguchi design for $\mathrm{VB}_{\max }$ and $\mathrm{Ra}$, respectively.

Table 1. Lathe parameters and established levels.

\begin{tabular}{ccccc}
\hline Symbol & Cutting parameters & Level 1 & Level 2 & Level 3 \\
\hline Vc & Cutting speed $(\mathrm{m} / \mathrm{min})$ & 150 & 200 & 220 \\
ap & Depth of cut $(\mathrm{mm})$ & 0.2 & 0.4 & 0.6 \\
$\mathrm{f}$ & Feed rate $(\mathrm{mm} / \mathrm{rev})$ & 0.20 & 0.25 & 0.30 \\
\hline
\end{tabular}

Table 2. Orthogonal array $\mathrm{L}_{9}$ of Taguchi, results of experiment and $\mathrm{S} / \mathrm{N}$ ratios values.

\begin{tabular}{|c|c|c|c|c|c|c|c|}
\hline \multirow{2}{*}{$\begin{array}{c}\text { No. } \\
\text { experiment }\end{array}$} & \multicolumn{3}{|c|}{ Controlling factors } & \multirow{2}{*}{$\begin{array}{c}\mathrm{Ra} \\
(\mu \mathrm{m})\end{array}$} & \multirow{2}{*}{$\begin{array}{l}\mathrm{S} / \mathrm{N} \\
(\mathrm{dB})\end{array}$} & \multirow{2}{*}{$\begin{array}{l}\mathrm{VB}_{\max } \\
(\mathrm{mm})\end{array}$} & \multirow{2}{*}{$\begin{array}{l}\mathrm{S} / \mathrm{N} \\
(\mathrm{dB})\end{array}$} \\
\hline & $\mathrm{Vc}(\mathrm{m} / \mathrm{min})$ & ap $(\mathrm{mm})$ & $\mathrm{f}(\mathrm{mm} / \mathrm{rev})$ & & & & \\
\hline 1 & 150 & 0.2 & 0.20 & 0.240 & 12.3958 & 0.873 & 1.17972 \\
\hline 2 & 150 & 0.4 & 0.25 & 1.102 & -0.8436 & 0.905 & 0.86703 \\
\hline 3 & 150 & 0.6 & 0.30 & 1.192 & -1.5255 & 0.939 & 0.54669 \\
\hline 4 & 200 & 0.2 & 0.25 & 0.140 & 17.0774 & 1.972 & -5.89814 \\
\hline 5 & 200 & 0.4 & 0.30 & 1.188 & -1.4963 & 0.508 & 5.88273 \\
\hline 6 & 200 & 0.6 & 0.20 & 0.492 & 6.1607 & 1.653 & -4.36546 \\
\hline 7 & 220 & 0.2 & 0.30 & 1.157 & -1.2667 & 0.640 & 3.87640 \\
\hline 8 & 220 & 0.4 & 0.20 & 0.978 & 0.1932 & 0.948 & 0.46383 \\
\hline 9 & 220 & 0.6 & 0.25 & 1.357 & -2.6516 & 1.235 & -1.83334 \\
\hline
\end{tabular}

$\mathrm{T}_{\mathrm{Ra}}($ surface roughness total mean value $)=0.8718 \mu \mathrm{m} ; \mathrm{T}_{\mathrm{VBmax}}($ flank wear total mean value $)=1.074 \mathrm{~mm}$. 
By performing a statistical analysis of the variance (ANOVA), the impact of each factor on the outputs is obtained and the process parameters statistically significant are identified. With the S/N and ANOVA analyses, the optimal combination of the process parameters can be predicted, these parameters optimize (minimize) the values of $\mathrm{VB}_{\max }$ and $\mathrm{Ra}$. The $3 \mathrm{D}$ response surface graphs are obtained by means of the response surface method (RMS) and the variation of the different parameters used in the experiment. The regression analysis was formulated, obtaining linear and quadratic regression models to predict the values of $\mathrm{VB}_{\max }$ and Ra. The data analysis described was done through the Minitab $17^{\text {Tn }}$ software.

\section{Results and Discussion}

\subsection{Analysis of the Signal-to-Noise (S/N) Ratio}

Surface roughness $(\mathrm{Ra})$ and maximum flank wear $\left(\mathrm{VB}_{\max }\right)$ were measured via the experimental design for each combination of the controlling factors by using Taguchi's technique, the optimization of the measured controlling factors were provided via $(\mathrm{S} / \mathrm{N})$ ratios. The lowest values of surface roughness and tool wear are quite relevant for quality improvement. Table 2 , shows the values for observations of $\mathrm{S} / \mathrm{N}$ ratios for $\mathrm{VB}_{\max }$ and $\mathrm{Ra}$. At the end of turning tests, the average values of the surface roughness and flank wear were calculated to be $\mathrm{Ra}=0.8718$ $\mu \mathrm{m} \mathrm{y} \mathrm{VB}_{\max }=1.074 \mathrm{~mm}$ respectively. The analysis about the effect of every controlling factor (Vc, ap, $\mathrm{f}$ ) on the surface roughness and flank wear was performed with $\mathrm{S} / \mathrm{N}$ ratios as listed in Table 3. The optimal level values for the controlling factors $\mathrm{Ra}$ and $\mathrm{VB}_{\max }$ are plotted in Figure 4 and Figure 5. The best level for each controlling factor was established according to the highest $\mathrm{S} / \mathrm{N}$ ratio among the levels. Based on the above mentioned; the levels and $\mathrm{S} / \mathrm{N}$ ratios for the factors giving the best Ra value were specified as factor Vc (Level 2, $\mathrm{S} / \mathrm{N}=7.2473$ ), factor ap(Level $1, \mathrm{~S} / \mathrm{N}=9.4022)$ and factor $\mathrm{f}$ (Level $1, \mathrm{~S} / \mathrm{N}=6.2499)$. In other words, an optimum Ra value was obtained with a cutting speed $(\mathrm{Vc})$ in level 2 $(200 \mathrm{~m} / \mathrm{min})$, at depth cut (ap) in level $1(0.2 \mathrm{~mm})$ and at a feed rate (f) in level 1 $(0.20 \mathrm{~mm} / \mathrm{rev})$, see Figure 4 . Similarly, the levels and $\mathrm{S} / \mathrm{N}$ ratios for the factors giving the best $\mathrm{VB}_{\max }$ were specified as factor $\mathrm{Vc}$ (Level $\left.1, \mathrm{~S} / \mathrm{N}=0.8645\right)$, factor

Table 3. $\mathrm{S} / \mathrm{N}$ response table for $\mathrm{Ra}$ and $\mathrm{VB}_{\max }$ factor.

\begin{tabular}{ccccccc}
\hline & \multicolumn{6}{c}{ Controlling factors } \\
\cline { 2 - 6 } Levels & \multicolumn{5}{c}{ Surface roughness (Ra) } & \multicolumn{3}{c}{ Flank wear (VB $\left.\mathrm{Vax}_{\text {max }}\right)$} \\
\cline { 2 - 7 } & $\mathrm{Vc}$ & $\mathrm{ap}$ & $\mathrm{f}$ & $\mathrm{Vc}$ & $\mathrm{ap}$ & $\mathrm{f}$ \\
\hline Level 1 & 3.3422 & $\mathbf{9 . 4 0 2 2}$ & $\mathbf{6 . 2 4 9 9}$ & $\mathbf{0 . 8 6 4 5}$ & -0.2807 & -0.9073 \\
Level 2 & $\mathbf{7 . 2 4 7 3}$ & -0.7156 & 4.5274 & -1.4603 & $\mathbf{2 . 4 0 4 5}$ & -2.2881 \\
Level 3 & -1.2417 & 0.6612 & -1.4295 & 0.8356 & -1.8840 & 3.4353 \\
Delta & 0.5573 & 0.5770 & 0.6090 & 2.3248 & 4.2886 & 5.7234 \\
\hline
\end{tabular}

Values in bold shows the most influential factor. 


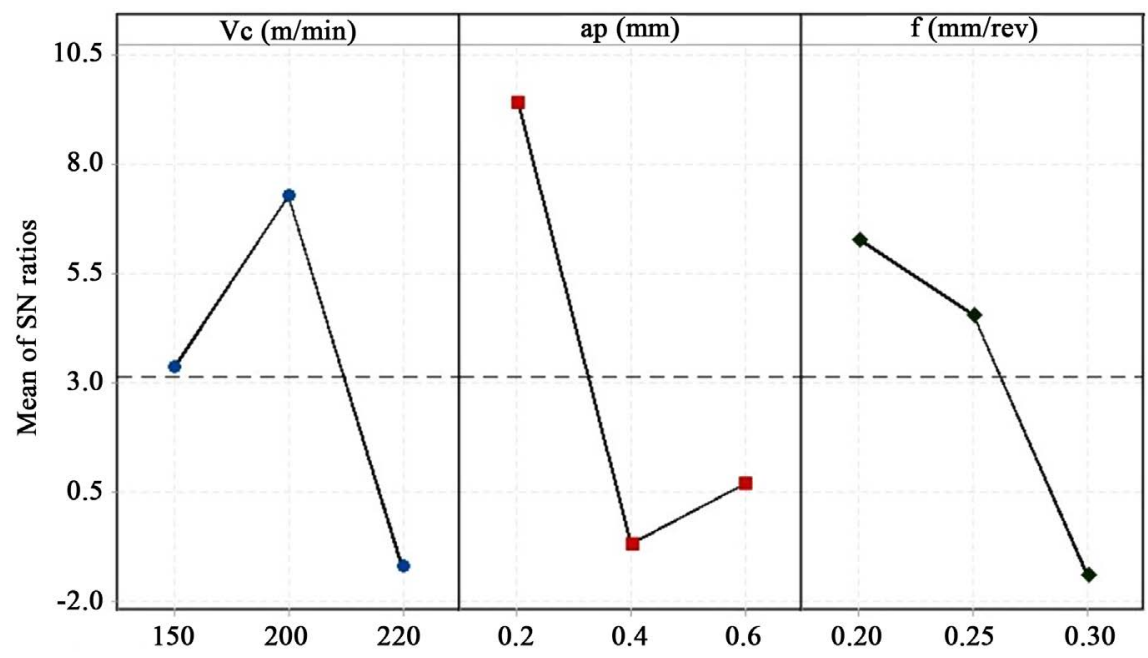

Figure 4. Effect of process parameters on average $\mathrm{S} / \mathrm{N}$ ratio for $\mathrm{Ra}$.

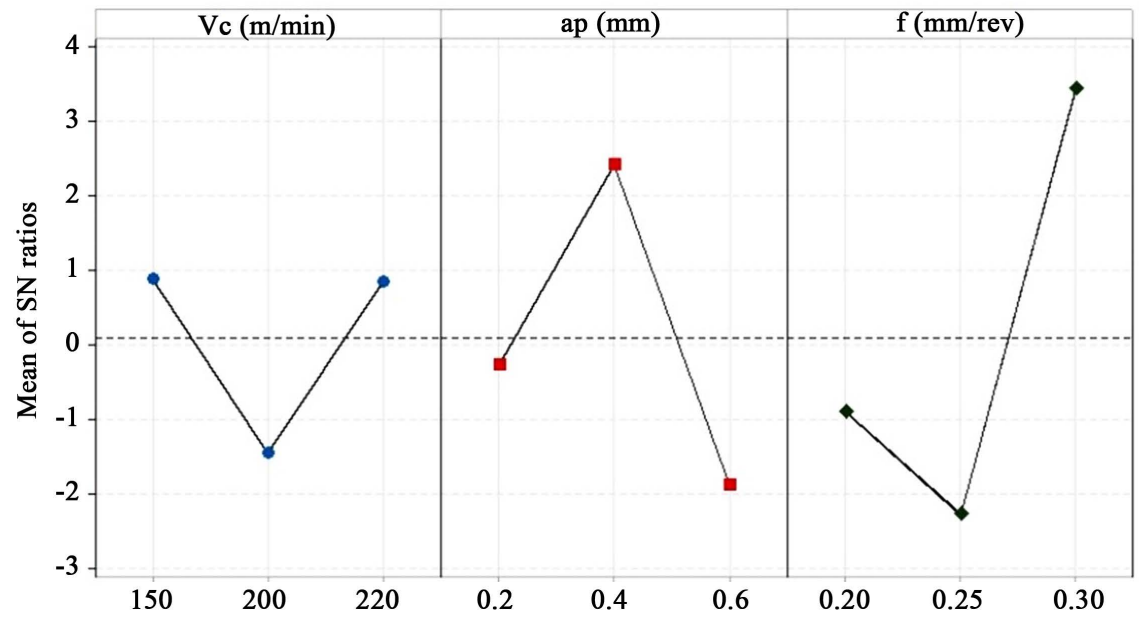

Figure 5. Effect of process parameters on average $\mathrm{S} / \mathrm{N}$ ratio for $\mathrm{VB}_{\max }$.

ap (Level 2, $\mathrm{S} / \mathrm{N}=2.4045)$ and factor $\mathrm{f}$ (Level 3, $\mathrm{S} / \mathrm{N}=3.4353$ ). From the point of machining conditions, the optimum $\mathrm{VB}_{\max }$ value was obtained with a cutting speed $(\mathrm{Vc})$ in level $1(150 \mathrm{~m} / \mathrm{min})$, at depth cut (ap) in level $2(0.4 \mathrm{~mm})$ and a feedrate $(\mathrm{f})$ in level $3(0.30 \mathrm{~mm} / \mathrm{rev})$, see Figure 5 .

\subsection{Evaluation of the Experimental Results}

Figure 6 shows that when increasing the depth of cut and feed rate, respectively; the surface roughness increases. The cutting speed has not significant direct effect on the surface roughness but interacts with the depth cut and feed rate parameters. The surface roughness is a function of feed rate; an increasing feed rate caused a significant increase in the Ra values. In [11] it was found that the best surface roughness was obtained when using high cutting speeds and low feed rates.

Figure 7 shows that the flank wears increases as a function of both: the cutting speed and depth of cut, in this case the flank wear increases slightly. The variation 

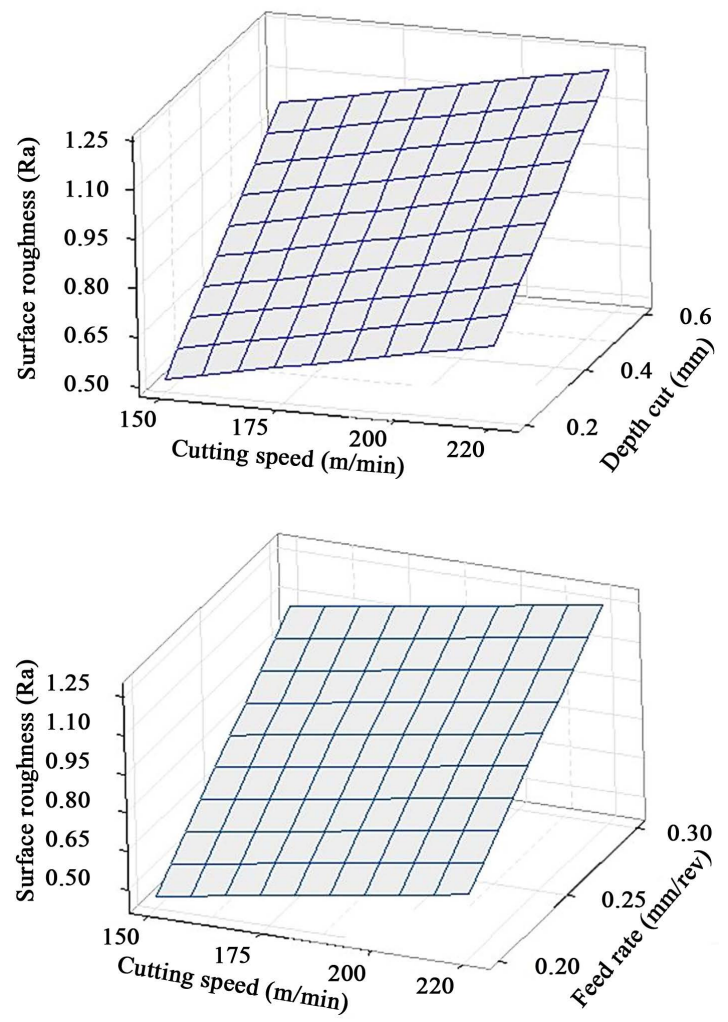

Figure 6. Effect of the cutting parameters on surface roughness.
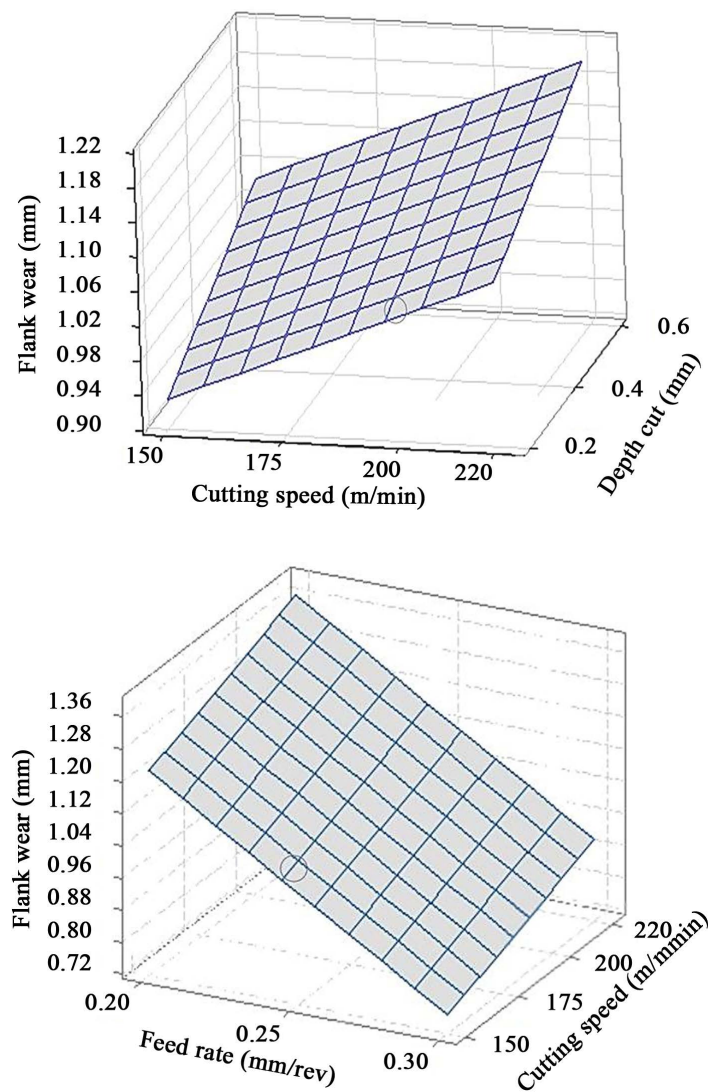

Figure 7. Effect of the cutting parameters on flank wear. 
in the increase of the feed rate and cutting speed had an important effect of interaction on the increase of flank wear; this may be a result of the rapid deformation of the sharp tool edge due to the thickness of the PVD coating. In [12] rapid deterioration of the cutting edge and catastrophic failure due to accelerated crater wear was normally observed when using PVD-coated insert after the removal of the thin layer of coating. In both cases, when increasing the cutting speed and the cutting depth, it was observed that increases the roughness of the machined surface and the wear of the cutting tool, therefore when increasing the cutting speed and the advance rate; increase the values of $\mathrm{Ra}$ and $\mathrm{VB}_{\max }$. It is verified that there is a relation between the wear of the cutting tool and the roughness of the machined surface obtained in the experiment.

The wear and failure for fracture in the flank of tool from the inserts used in the experiments for different cutting parameters are shown in Figure 8. High cutting speeds and feed rates were observed to be effective in the increase of flank wear during the experiment. Increasing the cutting speed of PVD coated tools has always been an important parameter in the increase of flank wear; for instance, by increasing the cutting speed promotes thermal and mechanical loading thus raising the temperatures in the cutting area, hence, speeding up the deformation of the cutting tools [13].

\subsection{Analysis of Variance (ANOVA)}

ANOVA was used to determine individual interactions of all the controlling factors during the test, as well as to analyze the effects of the cutting speed $(\mathrm{Vc})$, depth cut (ap) and feed rate (f), over Ra and $\mathrm{VB}_{\max }$. ANOVA results for surface roughness and flank wear are provided in Table 4 . The analysis was carried out

Table 4. ANOVA for surface roughness and flank wear.

\begin{tabular}{cccccc}
\hline $\begin{array}{c}\text { Variance } \\
\text { source }\end{array}$ & $\begin{array}{c}\text { Degree freedom } \\
(\mathrm{DoF})\end{array}$ & $\begin{array}{c}\text { Sum squares } \\
(\mathrm{SS})\end{array}$ & $\begin{array}{c}\text { Mean square } \\
(\mathrm{MS})\end{array}$ & F ratio & $\begin{array}{c}\text { Contribution rate } \\
(\%)\end{array}$ \\
\hline $\mathrm{Ra}$ & & & & & \\
$\mathrm{Vc}$ & 2 & 0.46924 & 0.23462 & 10.02 & 28.22 \\
$\mathrm{ap}$ & 2 & 0.58999 & 0.29499 & 12.60 & 35.50 \\
$\mathrm{f}$ & 2 & 0.55645 & 0.27823 & 11.89 & 33.47 \\
Error & 2 & 0.04681 & 0.02340 & - & 2.81 \\
Total & 8 & 1.66249 & - & - & 100 \\
$\mathrm{VB} \mathrm{m}_{\max }$ & & & & & \\
$\mathrm{Vc}$ & 2 & 0.4147 & 0.2074 & 1.61 & 23.31 \\
ap & 2 & 0.3922 & 0.1961 & 1.52 & 22.04 \\
$\mathrm{f}$ & 2 & 0.7146 & 0.3573 & 2.77 & 40.16 \\
Error & 2 & 0.2579 & 0.1289 & - & 14.49 \\
Total & 8 & 1.7793 & - & - & 100 \\
\hline
\end{tabular}

Values in bold shows the most influential factor. 


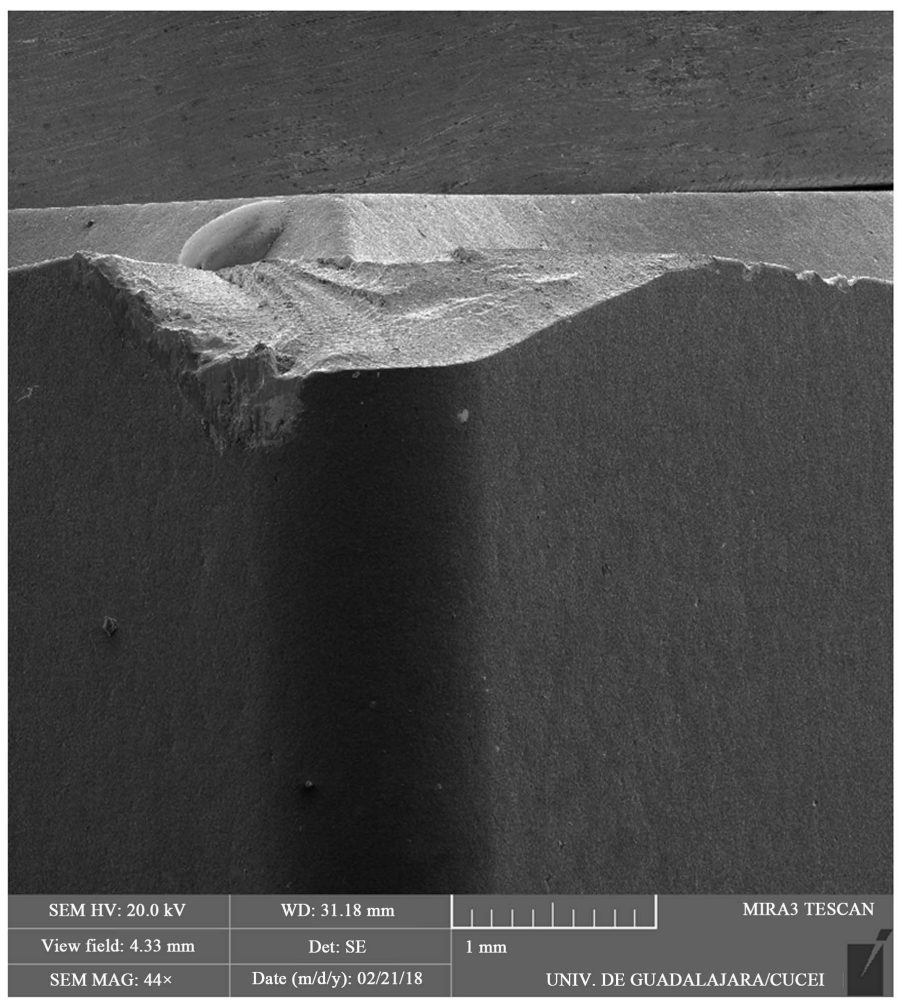

(a)

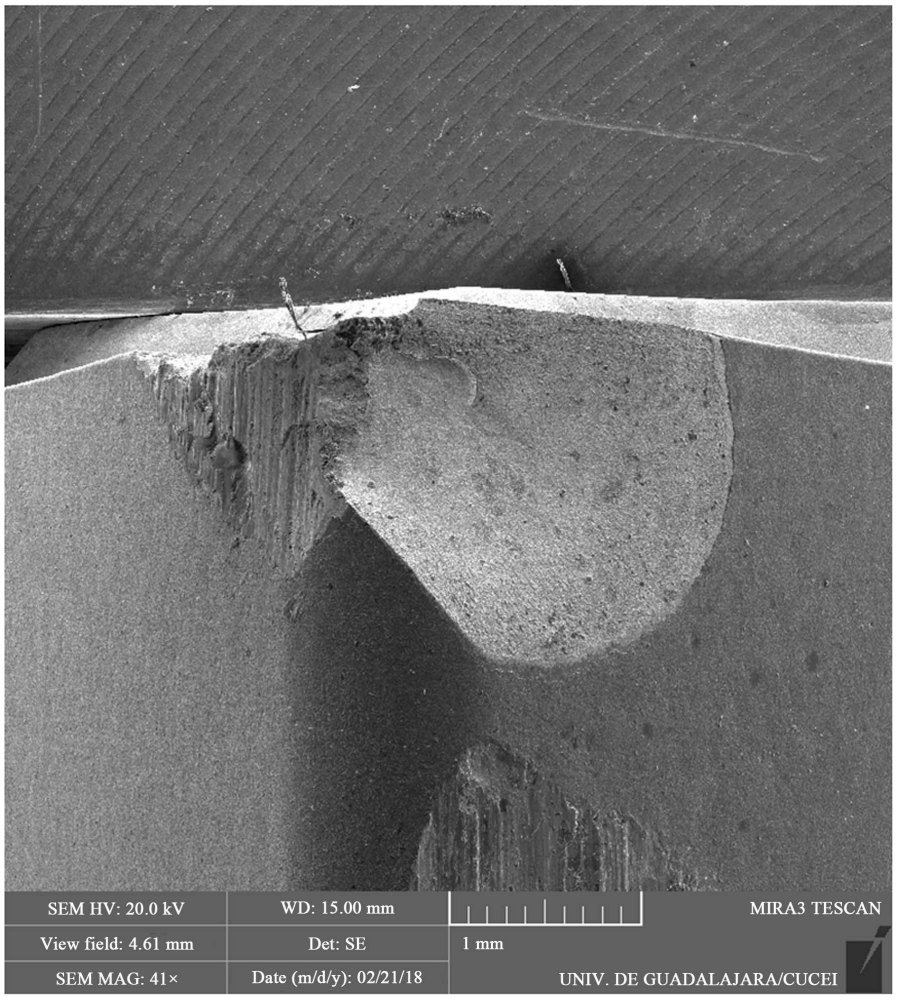

(b)

Figure 8. Images of tool flank wear and fracture, observation made in SEM: (a) Vc $=150$ $\mathrm{m} / \mathrm{min}, \mathrm{ap}=0.6 \mathrm{~mm}, \mathrm{f}=0.30 \mathrm{~mm} / \mathrm{rev}$; (b) $\mathrm{Vc}=220 \mathrm{~m} / \mathrm{min}, \mathrm{ap}=0.6 \mathrm{~mm}, \mathrm{f}=0.25$ $\mathrm{mm} / \mathrm{rev}$. 
at $5 \%$ significance level and a $95 \%$ confidence level. The significance statistic of control factors in ANOVA is determined by comparing the $\mathrm{F}$ values of each controlling factor. The factors with value higher of $\mathrm{F}$ have a significant effect on the response. The contribution rate of each parameter indicates the influence on $\mathrm{Ra}$ and $\mathrm{VB}_{\max }$ [14]. Table 4 indicates for Ra the contribution of each factor was: depth cut (factor ap 35.50\%), feed rate (factor $\mathrm{f} 33.47 \%$ ) and cutting speed (factor Vc 28.22\%). The most important factor affecting the surface roughness was the depth cut with contribution ratio of $35.50 \%$. For $\mathrm{VB}_{\text {max }}$ the percent contributions were found to be (f 40.16\%), (Vc 23.31\%) and (ap 22.04\%), respectively. This showed that the most effective factor on flank wear was feed rate $(40.16 \%)$. The percent of error was considerably low at $2.81 \%$ and $14.49 \%$ for $\mathrm{Ra}$ and $\mathrm{VB}_{\max }$ respectively.

\subsection{Analysis of Surface Roughness and Flank Wear}

In this study, the dependent variables are surface roughness (Ra) and flank wear $\left(\mathrm{VB}_{\max }\right)$, whereas the independent variables are cutting speed $(\mathrm{Vc})$, depth cut (ap) and feed rate (f). For obtaining predictive equations of the surface roughness and tool wear; regression analysis was used. These predictive equations were made for both linear and quadratic regression models. The predictive equations which were obtained by the linear regression model of surface roughness and flank wear are given below.

$$
\begin{gathered}
\mathrm{Ra}=-1.68+0.00277 \mathrm{Vc}+1.253 \mathrm{ap}+6.09 \mathrm{f} \\
\mathrm{R}^{2}=59.74 \% \text { y R }{ }^{2} \mathrm{adj}=35.58 \% \\
\mathrm{VB}_{\max }=1.69+0.00222 \mathrm{Vc}+0.28 \mathrm{ap}-4.61 \mathrm{f} \\
\mathrm{R}^{2}=21.28 \% \text { y R } \mathrm{R}^{2} \mathrm{adj}=0.0 \%
\end{gathered}
$$

Predictive equations upon quadratic regression of surface roughness and flank wear are given below:

$$
\begin{gathered}
\mathrm{Ra}=12.63-0.1679 \mathrm{Vc}+7.78 \mathrm{ap}+4.5 \mathrm{f}+0.000466 \mathrm{Vc}^{2}-8.16 \mathrm{ap}^{2}+3.3 \mathrm{f}^{2} \\
\mathrm{R}^{2}=97.18 \% \text { y } \mathrm{R}^{2} \mathrm{adj}=88.74 \% \\
\mathrm{VB}_{\max }=-30.70+0.2141 \mathrm{Vc}-11.25 \mathrm{ap}+120.9 \mathrm{f}-0.000447 \mathrm{Vc}^{2} \\
+13.21 \mathrm{ap}^{2}-177.5 \mathrm{f}^{2}-0.1933 \mathrm{Vc} * \mathrm{f} \\
\mathrm{R}^{2}=99.15 \% \text { y } \mathrm{R}^{2} \mathrm{adj}=93.21 \%
\end{gathered}
$$

A comparison of the experimental results and the predicted values obtained upon quadratic regression model are shown in Figure 9. There is an acceptable relationship among predicted values and experimental results. The effectivity of the model has been verified with $\mathrm{R}^{2}$ called coefficient of determination, it is used to judge the adequacy of the developed regression models [15]. The second order model explains about $97.18 \%$ and $99.15 \%$ of the variability of responses in predicting new observations compared to first order model. 


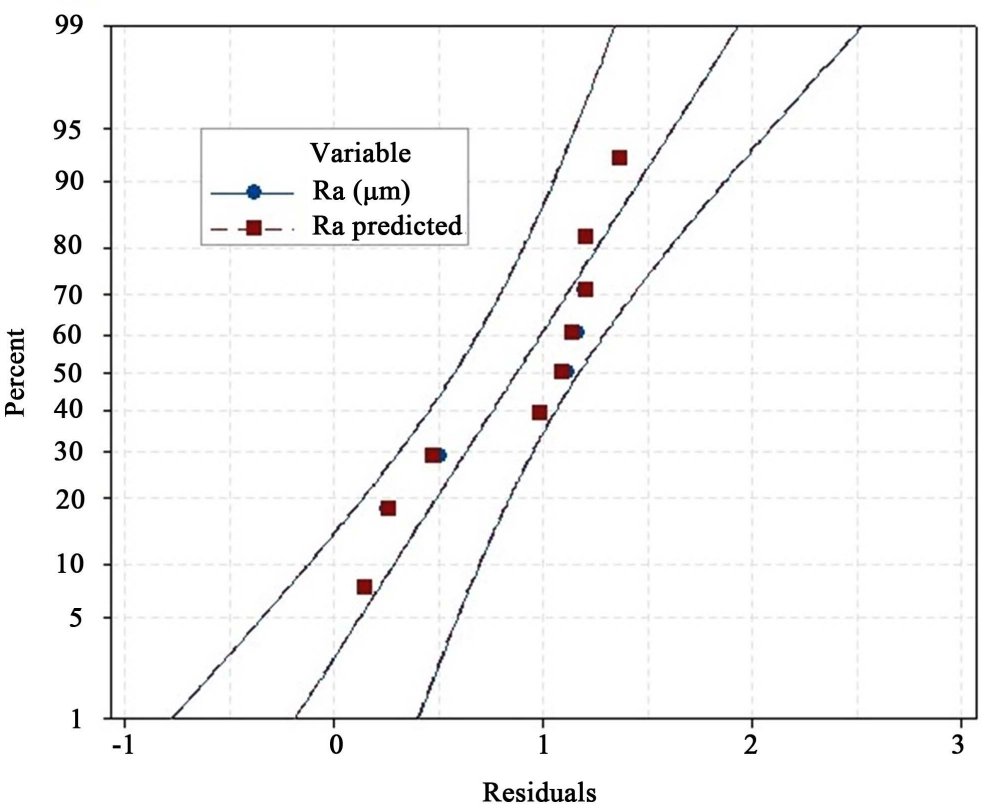

(a)

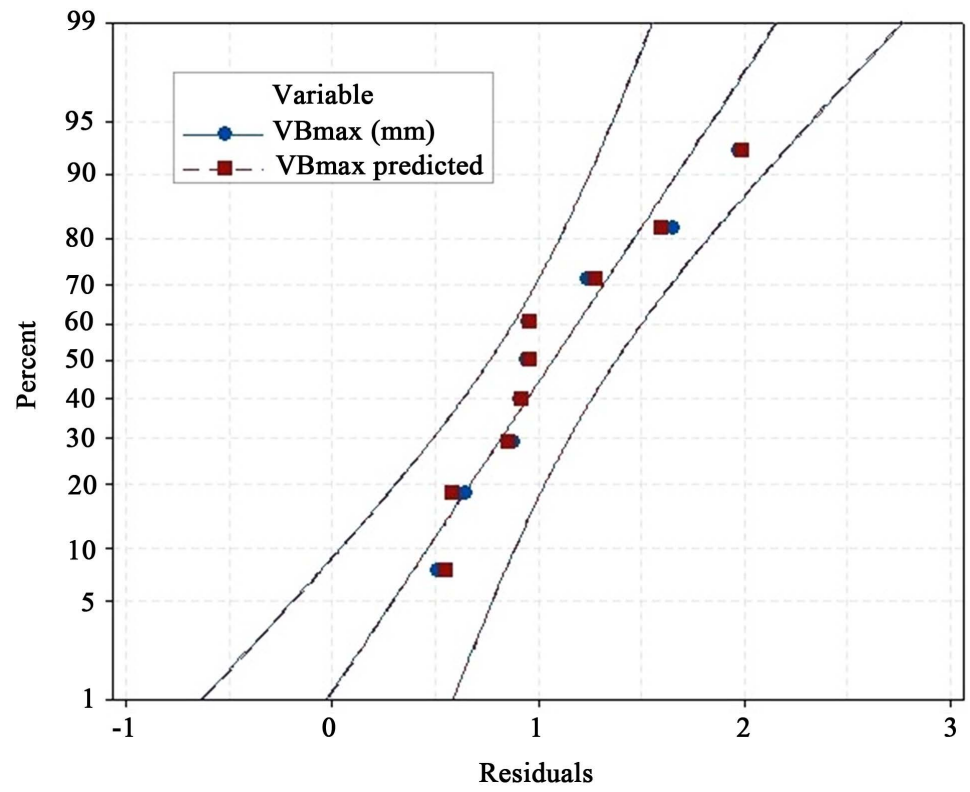

(b)

Figure 9. Comparison of the quadratic regression model with experimental results for Ra and $\mathrm{VB}_{\max }$.

\subsection{Estimation of Optimum Surface Roughness and Flank Wear}

When employing Taguchi optimization technique; a confirmation experiment is required for validating of the optimized condition [13]. By estimating optimum surface roughness and flank wear: Equations (6) and (7) were used respectively:

$$
\begin{gathered}
\mathrm{Ra}_{\text {opt }}=\left(\mathrm{Vc}_{2}-\mathrm{T}_{\mathrm{Ra}}\right)+\left(\mathrm{ap}_{1}-\mathrm{T}_{\mathrm{Ra}}\right)+\left(\mathrm{f}_{1}-\mathrm{T}_{\mathrm{Ra}}\right)+\mathrm{T}_{\mathrm{Ra}} \\
\mathrm{VB}_{\text {opt }}=\left(\mathrm{Vc}_{1}-\mathrm{T}_{\mathrm{VB}_{\text {max }}}\right)+\left(\mathrm{ap}_{2}-\mathrm{T}_{\mathrm{VB}_{\max }}\right)+\left(\mathrm{f}_{3}-\mathrm{T}_{\mathrm{VB}_{\text {max }}}\right)+\mathrm{T}_{\mathrm{VB}_{\max }}
\end{gathered}
$$


Here, $\left(\mathrm{Vc}_{2}, \mathrm{ap}_{1}, \mathrm{f}_{1}\right)$ and $\left(\mathrm{Vc}_{1}, \mathrm{ap}_{2}, \mathrm{f}_{3}\right)$ represent the optimum level average values of surface roughness $\left(\mathrm{Ra}_{\mathrm{opt}}\right)$ and flank wear $\left(\mathrm{VB}_{\mathrm{opt}}\right)$ respectively as listed in Table 5. $\mathrm{T}_{\mathrm{Ra}}$ and $\mathrm{T}_{\mathrm{VB}_{\max }}$ state the average of all of the Ra and $\mathrm{VB}_{\max }$ values obtained from the experimental study (Table 1).

Substituting the values mentioned of the Table 1 and Table 5 into the Equations (6) and (7) respectively, as a result of the calculations, it was estimated that $\mathrm{Ra}_{\text {opt }}=0.054 \mu \mathrm{m}$ and $\mathrm{VB}_{\text {opt }}=0.238 \mathrm{~mm}$.

Whether the system had realized the optimization accurately enough needed to be evaluated. For this purpose, the following equations were used in the specification of the confidence interval $(\mathrm{Cl})$ for estimated surface roughness and flank wear [13]:

$$
\begin{gathered}
\mathrm{CI}_{\mathrm{Ra}, \mathrm{VB} \text { max }}=\sqrt{\mathrm{F}_{\alpha, 1, \mathrm{f}_{\mathrm{e}}} \mathrm{V}_{\mathrm{e}}\left[\frac{1}{\mathrm{n}_{\text {eff }}}+\frac{1}{\mathrm{R}}\right]} \\
\mathrm{n}_{\text {eff }}=\frac{\mathrm{N}}{1+\mathrm{T}_{\text {dof }}}
\end{gathered}
$$

Here, $\mathrm{F}_{\alpha, 1, \mathrm{f}_{\mathrm{e}}}$ is the $\mathrm{F}$ ratio at a $95 \%$ confidence, $\alpha$ is the significance level, $\mathrm{f}_{\mathrm{e}}$ is the degrees-of-freedom of error, $\mathrm{V}_{\mathrm{e}}$ is error variance, $\eta_{\text {eff }}$ is the effective number of replications, $\mathrm{R}$ is the number of replications for confirmation experiments, Equation (8). $\mathrm{N}$ is the total number of experiments, and $\mathrm{T}_{\text {dof }}$ is the total main factor degrees of freedom, Equation (9). $\mathrm{F}_{0.05,1,2}=18.51$ (from $\mathrm{F}$ test table), $\mathrm{V}_{\mathrm{eRa}}=$ 0.02340 and $\mathrm{V}_{\mathrm{eVB}_{\max }}=0.1289$ (Table 4), $\mathrm{R}=1$ (Equation (8)), $\mathrm{N}=9, \mathrm{~T}_{\mathrm{dof}}=6$ and $\eta_{\text {eff }}=1.29$ (Equation (9)).

By using the Equations (8) and (9) the confidence intervals were calculated as $\mathrm{CI}_{\mathrm{Ra}}= \pm 0.876$ and $\mathrm{CI}_{\mathrm{VB}_{\max }}= \pm 2.06$ The estimated average optimal surface roughness and flank wear with the confidence interval at $95 \%$ confidence is:

$$
\begin{gathered}
{\left[\mathrm{Ra}_{\text {opt }}-\mathrm{CI}_{\mathrm{Ra}}\right]<\mathrm{Ra}_{\text {exp }}<\left[\mathrm{Ra}_{\text {opt }}-\mathrm{CI}_{\mathrm{Ra}}\right], \text { i.e.; }} \\
{[0.054-0.876]<0.14<[0.054+0.876]=-0.822<0.14<0.93} \\
{\left[\mathrm{VB}_{\text {max,opt }}-\mathrm{CI}_{\left.\mathrm{VB}_{\max }\right]}\right]<\mathrm{VB}_{\text {max,exp }}<\left[\mathrm{VB}_{\text {max opt }}-\mathrm{CI}_{\mathrm{VB}_{\max }}\right], \text { i.e.; }} \\
{[0.238-2.06]<0.909<[0.238+2.06]=-1.8<0.909<2.298}
\end{gathered}
$$

Table 5. Mean response table for $\mathrm{Ra}$ and $\mathrm{VB}_{\max }$ factor.

\begin{tabular}{ccccccc}
\hline & \multicolumn{6}{c}{ Controlling factors } \\
\cline { 2 - 7 } Levels & \multicolumn{5}{c}{ Surface roughness $(\mathrm{Ra})$} & \multicolumn{3}{c}{ Flank wear $\left(\mathrm{VB}_{\max }\right)$} \\
\cline { 2 - 7 } & $\mathrm{Vc}$ & $\mathrm{ap}$ & $\mathrm{f}$ & $\mathrm{Vc}$ & $\mathrm{ap}$ & $\mathrm{f}$ \\
\hline Level 1 & 0.8447 & $\mathbf{0 . 5 1 2 3}$ & $\mathbf{0 . 5 7 0 0}$ & $\mathbf{0 . 9 0 5 7}$ & 1.1617 & 1.1580 \\
Level 2 & $\mathbf{0 . 6 0 6 7}$ & 1.0893 & 0.8663 & 1.3777 & $\mathbf{0 . 7 8 7 0}$ & 1.3707 \\
Level 3 & 1.1640 & 1.0137 & 1.1790 & 0.9410 & 1.2757 & $\mathbf{0 . 6 9 5 7}$ \\
Delta & 0.5573 & 0.5770 & 0.6090 & 0.4710 & 0.4887 & 0.6750 \\
\hline
\end{tabular}

Values in bold shows the $\mathrm{Ra}$ and $\mathrm{VB}_{\max }$ values obtained from the experimental study. 
The $\mathrm{Ra}_{\exp }$ and $\mathrm{VB}_{\max , \exp }$ values, obtained from the experimental study stayed within the confidence interval limits. Thus, the system optimization for surface roughness and flank wear was achieved using the Taguchi method at a significance level of 0.05 .

\subsection{Confirmation Tests}

Confirmation tests of the controlling factors were made for the Taguchi method and regression equations at optimum and random levels. In Table 6, the comparison of experimental results and the predicted values (obtained by Taguchi method and regression equations 4 to 7) are listed. The predicted values and the experimental values are very close to each other in quadratic regression models for $\mathrm{Ra}$ and $\mathrm{VB}_{\max }$. For reliable statistical analyses, error values must be less than $20 \%$ [16]. Although the error percentages calculated in the flank wear are higher than the ones in surface roughness, they are within acceptable limits. Therefore, the results obtained from the confirmation tests reflect successful optimization.

\section{Conclusion}

In this study, the Taguchi method was used to determine optimal machining parameters in the turning of hardened steel AISI D2 by employing PVD-TiAlN coated WC inserts upon dry machining conditions. The optimum levels of the controlling factors for minimizing the surface roughness and flank wear using $\mathrm{S} / \mathrm{N}$ rates were determined. According to the analysis of variance (ANOVA), it was found that the depth cut was the most significant parameter for surface

Table 6. Predicted values and confirmation test results by Taguchi method and regression equations.

\begin{tabular}{|c|c|c|c|c|c|c|c|c|c|}
\hline \multirow{2}{*}{ Level } & \multicolumn{3}{|c|}{ Taguchi method } & \multicolumn{3}{|c|}{$\begin{array}{c}\text { Lineal regression } \\
\text { equations }\end{array}$} & \multicolumn{3}{|c|}{$\begin{array}{l}\text { Quadratic } \\
\text { regression equations }\end{array}$} \\
\hline & Exp. & Pred. & Error (\%) & Exp. & Pred. & Error (\%) & Exp. & Pred. & Error (\%) \\
\hline \multicolumn{10}{|l|}{$\mathrm{Ra}(\mu \mathrm{m})$} \\
\hline $\begin{array}{c}\mathrm{Vc}_{2} \mathrm{ap}_{1} \mathrm{f}_{1} \\
\text { (Optimum) }\end{array}$ & 0.165 & 0.054 & 66.909 & 0.165 & 0.647 & 292.181 & 0.165 & 0.137 & 16.806 \\
\hline $\begin{array}{c}\mathrm{Vc}_{1} \mathrm{ap}_{2} \mathrm{f}_{2} \\
\text { (Random 2) }\end{array}$ & 1.102 & 0.818 & 25.708 & 1.102 & 0.7592 & 31.107 & 1.102 & 1.080 & 1.916 \\
\hline $\begin{array}{c}\mathrm{Vc}_{3} \mathrm{ap}_{1} \mathrm{f}_{3} \\
\text { (Random 7) }\end{array}$ & 1.157 & 1.111 & 3.915 & 1.157 & 1.007 & 12.964 & 1.157 & 1.131 & 2.167 \\
\hline \multicolumn{10}{|l|}{$\mathrm{VB}_{\max }(\mathrm{mm})$} \\
\hline $\begin{array}{c}\mathrm{Vc}_{1} \mathrm{ap}_{2} \mathrm{f}_{3} \\
\text { (Optimum) }\end{array}$ & 0.909 & 0.238 & 73.729 & 0.909 & 1.155 & 27.062 & 0.909 & 0.916 & 0.869 \\
\hline $\begin{array}{c}\mathrm{Vc}_{1} \mathrm{ap}_{2} \mathrm{f}_{2} \\
\text { (Random 2) }\end{array}$ & 0.905 & 0.913 & 0.972 & 0.905 & 0.980 & 8.287 & 0.905 & 0.853 & 5.679 \\
\hline $\begin{array}{c}\mathrm{Vc}_{3} \mathrm{ap}_{1} \mathrm{f}_{3} \\
\text { (Random 7) }\end{array}$ & 0.640 & 0.648 & 1.375 & 0.640 & 0.848 & 32.562 & 0.640 & 0.582 & 8.937 \\
\hline
\end{tabular}


roughness, whereas the feed rate was the most significant parameter for flank wear. The optimal conditions for surface roughness and flank wear were obtained: $\mathrm{Vc}_{2} \mathrm{ap}_{1} \mathrm{f}_{1}(\mathrm{Vc}=200 \mathrm{~m} / \mathrm{min}$, ap $=0.2 \mathrm{~mm}$ and $\mathrm{f}=0.20 \mathrm{~mm} / \mathrm{rev})$ and $\mathrm{Vc}_{1} \mathrm{ap}_{2} \mathrm{f}_{3}(\mathrm{Vc}=150 \mathrm{~m} / \mathrm{min}$, ap $=0.4 \mathrm{~mm}$ and $\mathrm{f}=0.3 \mathrm{~mm} / \mathrm{rev})$, respectively. Results upon the confirmation test measured values, showed that the Taguchi method was quite effective in the optimization of machining parameters.

\section{Acknowledgements}

To PRODEP, for the scholarship granted in the completion of postgraduate studies in the Doctorate in Advanced Manufacturing in CIATEQ, Aguascalientes, México. To the University of Colima for the facilities and support to carry out the Doctorate studies. To the Autonomous University of Zacatecas, through the postgraduate Master of Science and Materials Engineering, for the support provided in the realization and completion of this experimental research. To the Autonomous University of Guadalajara for the support in the analysis through SEM.

\section{Conflicts of Interest}

The authors declare no conflicts of interest regarding the publication of this paper.

\section{References}

[1] Asiltürk, I. and Akkuş, H. (2011) Determining the Effect of Cutting Parameters on Surface Roughness in Hard Turning Using the Taguchi Method. Measurement. Journal of the International Measurement Confederation, 44, 1697-1704. https://doi.org/10.1016/j.measurement.2011.07.003

[2] Sahoo, A.K. and Sahoo, B. (2013) A Comparative Study on Performance of Multilayer Coated and Uncoated Carbide Inserts when Turning AISI D2 Steel under Dry Environment. Measurement. Journal of the International Measurement Confederation, 46, 2695-2704. https://doi.org/10.1016/j.measurement.2013.04.024

[3] Zheng, G., Xu, R., Cheng, X., Zhao, G., Li, L. and Zhao, J. (2018) Effect of Cutting Parameters on Wear Behavior of Coated Tool and Surface Roughness in High-Speed Turning of 300M. Measurement. Journal of the International Measurement Confederation, 125, 99-108.

https://doi.org/10.1016/j.measurement.2018.04.078

[4] Khan, S.A., Umar, M., Saleem, M.Q., Mufti, N.A. and Raza, S.F. (2018) Experimental Investigations on Wiper Inserts' Edge Preparation, Workpiece Hardness and Operating Parameters in Hard Turning of AISI D2 Steel. Journal of Manufacturing Processes, 34, 187-196. https://doi.org/10.1016/j.jmapro.2018.06.004

[5] Davim, J.P. and Figueira, L. (2007) Machinability Evaluation in Hard Turning of Cold Work Tool Steel (D2) with Ceramic Tools Using Statistical Techniques. Materials \& Design, 28, 1186-1191. https://doi.org/10.1016/j.matdes.2006.01.011

[6] Onuoha, O.J., Abu, J.O., Lawal, S.A., Mudiare, E. and Adeyemi, M.B. (2016) Determining the Effect of Cutting Fluids on Surface Roughness in Turning AISI $1330 \mathrm{Al}-$ loy Steel Using Taguchi Method. Modern Mechanical Engineering, 06, 51-59. https://doi.org/10.4236/mme.2016.62006 
[7] Özel, T., Karpat, Y., Figueira, L. and Davim, J.P. (2007) Modelling of Surface Finish and Tool Flank Wear in Turning of AISI D2 Steel with Ceramic Wiper Inserts. Journal of Materials Processing Technology, 189, 192-198. https://doi.org/10.1016/j.jmatprotec.2007.01.021

[8] Sharma, J. and Sidhu, B.S. (2014) Investigation of Effects of Dry and near Dry Machining on AISI D2 Steel Using Vegetable Oil. Journal of Cleaner Production, 66, 619-623. https://doi.org/10.1016/j.jclepro.2013.11.042

[9] Sahoo, A.K. and Sahoo, B. (2012) Experimental Investigations on Machinability Aspects in Finish Hard Turning of AISI 4340 Steel Using Uncoated and Multilayer Coated Carbide Inserts. Measurement. Journal of the International Measurement Confederation, 45, 2153-2165. https://doi.org/10.1016/j.measurement.2012.05.015

[10] Shetty, R., Pai, R.B., Rao, S.S. and Nayak, R. (2009) Taguchi's Technique in Machining of Metal Matrix Composites. The Journal of the Brazilian Society of $\mathrm{Me}$ chanical Sciences and Engineering, 31, 12-20. https://doi.org/10.1590/S1678-58782009000100003

[11] Lima, J.G., Ávila, R.F., Abrão, A.M., Faustino, M. and Davim, J.P. (2005) Hard Turning: AISI 4340 High Strength Low Alloy Steel and AISI D2 Cold Work Tool Steel. Journal of Materials Processing Technology, 169, 388-395.

https://doi.org/10.1016/j.jmatprotec.2005.04.082

[12] Chinchanikar, S. and Choudhury, S.K. (2015) Machining of Hardened Steel-Experimental Investigations, Performance Modeling and Cooling Techniques: A Review. International Journal of Machine Tools and Manufacture, 89, 95-109. https://doi.org/10.1016/j.ijmachtools.2014.11.002

[13] Kivak, T. (2014) Optimization of Surface Roughness and Flank Wear Using the Taguchi Method in Milling of Hadfield Steel with PVD and CVD Coated Inserts. Measurement: Journal of the International Measurement Confederation, 50, 19-28. https://doi.org/10.1016/j.measurement.2013.12.017

[14] Sarikaya, M. and Güllü, A. (2014) Taguchi Design and Response Surface Methodology Based Analysis of Machining Parameters in CNC Turning under MQL. Journal of Cleaner Production, 65, 604-616. https://doi.org/10.1016/j.jclepro.2013.08.040

[15] Mandal, N., Doloi, B., Mondal, B. and Das, R. (2011) Optimization of Flank Wear Using Zirconia Toughened Alumina (ZTA) Cutting Tool: Taguchi Method and Regression Analysis. Measurement. Journal of the International Measurement Confederation, 44, 2149-2155. https://doi.org/10.1016/j.measurement.2011.07.022

[16] Cetin, M.H., Ozcelik, B., Kuram, E. and Demirbas, E. (2011) Evaluation of Vegetable Based Cutting Fluids with Extreme Pressure and Cutting Parameters in Turning of AISI 304L by Taguchi Method. Journal of Cleaner Production, 19, 2049-2056. https://doi.org/10.1016/j.jclepro.2011.07.013 